\title{
De invloed van het taalstimuleringsprogramma Boekenbas op het geletterde klimaat in het gezin
}

Boekenbas is een taalstimuleringsprogramma dat beoogt bij te dragen aan de geletterde ontwikkeling van jonge kinderen. Onderzoek in 1999-2005 bij een cohort pasgeborenen liet positieve effecten zien van Boekenbas op de spraaktaalontwikkeling van de kinderen op 2- en 3-jarige leeftijd. Er is een vervolgonderzoek uitgevoerd, om na te gaan of gezinnen met een kind die aan Boekenbas hadden deelgenomen op langere termijn werden gekenmerkt door meer individuele en gezamenlijke geletterde activiteiten, positievere attitudes en een groter boekenaanbod dan gezinnen die niet hadden deelgenomen. Daartoe werd in 2008 een vragenlijst over het geletterde klimaat in het gezin voorgelegd aan de ouders van de 319 deelnemers aan het oorspronkelijke onderzoek. De respons bedroeg $67 \%$. De belangrijkste bevinding is dat de Boekenbasdeelnemers tweemaal zoveel kans hebben op te groeien in een gezin met een voor de geletterde ontwikkeling gunstig gezinsprofiel dan de deelnemers in de controlegroep.

\section{Inleiding}

Kinderen in de leeftijd van o tot 4 jaar maken belangrijke ontwikkelingen door in hun mondelinge taalvaardigheid en verwerven vaardigheden die van belang zijn voor hun latere lees- en schrijfontwikkeling. Bij het stimuleren van de taalontwikkeling van kinderen gaat de aandacht dan ook steeds meer uit naar de voorschoolse periode. Boekenbas is een taalstimuleringsprogramma dat beoogt de geletterde omgeving van jonge kinderen te bevorderen en daardoor bij te dragen aan de geletterde ontwikkeling van deze leeftijdsgroep..$^{1,2}$

De geletterde omgeving - ook wel genoemd home literacy environment ${ }^{3}$ of geletterd gezinsklimaat ${ }^{4}$ - wordt in onderzoek op verschillende manieren gemeten. Sommige oudere studies gaan uit van een vrij beperkte definitie en kijken bijvoorbeeld alleen naar voorleesfrequentie.5,6 In recenter uitgevoerde studies wordt uitgegaan van een meerdimensionale benadering. Zo richten verschillende onderzoekers zich ook op andere ouder-kindactiviteiten dan voorlezen, zoals liedjes zingen, versjes zeggen en bibliotheekbezoek, die zij vervolgens onderbrengen in gezinsprofielen. ${ }^{7-9}$ In andere studies worden ook de individuele geletterde activiteiten van ouders ${ }^{9,10}$ en de materiële leesomgeving 3 onderzocht. Ten slotte zijn er studies waarin behalve gedrag ook motivatie wordt bestudeerd. Daarin wordt bijvoorbeeld nagegaan hoe ouders denken over het belang van (voor)lezen en de relatie daarvan met de leesmotivatie van kinderen. ${ }^{11,12}$

Hoewel Boekenbas erop is gericht het geletterde gezinsklimaat te bevorderen, is in het onderzoek naar het effect van het programma tot op heden alleen gekeken naar de invloed op de vaardigheden van kinderen. Zo heeft eerder onderzoek bij een cohort pasgeborenen
(1999-2001) laten zien dat het programma op korte termijn (leeftijd 2 en 3 jaar) positieve effecten heeft op de spraaktaalontwikkeling., ${ }^{1,2,13}$ Effecten op de middellange termijn (leeftijd 4 jaar) konden niet worden aangetoond. In het licht van eerdere, met name Amerikaanse studies waarin positieve effecten zijn vastgesteld van deelname aan ouder-kindprogramma's op het geletterde gezinsklimaat, is een vervolgonderzoek verricht naar de relatie tussen Boekenbasdeelname en aandacht voor geletterdheid in het gezin. ${ }^{14-16}$ De centrale hypothese hierbij was dat gezinnen met een kind die aan Boekenbas hadden deelgenomen op langere termijn zouden worden gekenmerkt door een positiever geletterd klimaat dan nietdeelnemende gezinnen, dat wil zeggen, door meer individuele en gezamenlijke geletterde activiteiten, positievere attitudes ten aanzien van geletterde activiteiten en een groter boekenaanbod.

\section{Methode}

\section{Onderzoekspopulatie}

Het cohort dat oorspronkelijk deelnam aan de interventiestudie bestond uit 319 eerstgeborenen in de periode 1999-2001 in Overijssel en Flevoland. De ouders van 91 van alle 134 eerstgeborenen in Urk en 87 van de 101 eerstgeborenen in Staphorst (geboortejaar 2000-2001) namen deel aan de Boekenbasinterventie. De ouders van 80 eerstgeborenen in Urk (geboortejaar 1999) en van 61 eerstgeboren in Nieuwleusen (geboortejaar 2000-2001) vormden de controlegroep. . $^{2,13}$

In 2008 is met medewerking van directie, leerkrachten en intern begeleiders van de basisscholen, een vragenlijst meegegeven aan de kinderen die in het oorspronke-

F.C.C.M. Bunge-van Lent, arts jeugdgezondheidszorg, Zorggroep Oude en Nieuwe Land, Steenwijk. R.C.M. van Steensel, taalkundige, Research Institute for Child Development and Education en Kohnstamm Instituut, Universiteit van Amsterdam. P. van Dommelen, statisticus, TNO, Leiden. A. van Kleij-van Rossum, arts jeugdgezondheidszorg, Carinova, Raalte. P.H. Verkerk, jeugdarts-epidemioloog, TNO, Leiden. M.M. BoereBoonekamp, arts maatschappij en gezondheid, TNO, Leiden. Correspondentieadres: TNO, postbus 2215, 2301 CE, Leiden, magda.boere@tno.nl. 
lijke cohort zaten, voor hun ouders. De vragenlijst is door 214 ouders geretourneerd (respons 67\%); 106 van hen hadden deelgenomen aan Boekenbas, 108 niet.

\section{Interventie}

Boekenbas bestaat uit een uitleg door de jeugdverpleegkundige in de eerste maand na de geboorte. Daarna volgen 10 huisbezoeken in de eerste 2 levensjaren door een speciaal opgeleide (Boekenbas)moeder. Tijdens deze huisbezoeken wordt ingegaan op de spraaktaalontwik keling van het kind en krijgt de ouder een boekje om samen met het kind te bekijken. Bovendien vonden (in Staphorst) 5 groepsbijeenkomsten plaats, waarin de jeugdverpleegkundige, samen met een Boekenbasmoeder, voorlichting gaf over taalontwikkeling en ontluikende geletterdheid. Het streven is dat deelnemende gezinnen hun kind(eren) elke dag tussen de 20 en 30 minuten voorlezen en/of met hun kind vertel-, kijk-, praat- en speelactiviteiten doen.

\section{Meetinstrument}

Om het geletterde gezinsklimaat te meten, is bij ouders een vragenlijst afgenomen. De 15 vragen waren verdeeld over de volgende categorieën:

1. Frequentie van individuele geletterde activiteiten van de ouders en, eventueel, van het kind: kranten lezen, tijdschriften/weekbladen lezen, boeken lezen. Aanvullend is gevraagd naar de frequentie van televisiekijken en computergebruik als potentieel 'concurrerende' activiteiten. Voorbeeldvraag: 'Worden er bij u thuis door moeder boeken gelezen?' Antwoordmogelijkheden: nee / ja, 1 à 2 boeken per jaar / ja, 1 à 2 boeken per maand / ja 1 boek per week / ja, meer dan 1 boek per week.'

2. Frequentie van gezamenlijke ouder-kindactiviteiten: voorlezen, verhaaltjes vertellen, samen liedjes zingen / rijmpjes zeggen. Voorbeeldvraag: 'Wordt uw kind wel eens voorgelezen?' Antwoordmogelijkheden: ja, iedere dag / ja, een paar keer per week / ja, een paar keer per maand / ja, heel soms / nee, nooit.

3. Attitudes ten aanzien van gezamenlijke geletterde activiteiten: attitudes van de ouder ten aanzien van voorlezen, attitudes van het kind ten aanzien van voorlezen, verhaaltjes vertellen, liedjes zingen / versjes zeggen. Voorbeeldvraag: 'Ik heb erg veel plezier in voorlezen.' Antwoordmogelijkheden: helemaal mee eens / mee eens / geen mening / mee oneens / helemaal mee oneens.

4. Materiële leesomgeving: aantal kinderboeken in huis, bibliotheekbezoek. Voorbeeldvraag: 'Hoeveel kinderboeken heeft u thuis?' Antwoordmogelijkheden: geen / minder dan 5 / tussen de 5 en 10 / tussen de 10 en 25 / meer dan 25.'

\section{Analyse}

De uitkomstvariabelen voor de effectanalyses zijn als volgt opgebouwd. Eerst werd nagegaan of de afzonder- lijke vragen in de vragenlijst konden worden terugge bracht tot een beperkt aantal overkoepelende categorieen of 'componenten'. Hiervoor werd gebruik gemaakt van principale componentenanalyses (PCA) met varimaxrotatie. Er werden 2 van zulke PCA's uitgevoerd: een met de items die betrekking hadden op de frequentie van (individuele en gezamenlijke) geletterde activiteiten en een met de items die betrekking hadden op attitudes ten aanzien van gezamenlijke geletterde activiteiten. Om vast te stellen of een set van vragen daadwerkelijk samen een component vormden, zijn de volgende criteria gebruikt: componenten met een eigenwaarde van minimaal 1 zijn nader geanalyseerd en componentladingen van minimaal o,4 zijn als significant beschouwd. Nadat de componenten waren vastgesteld, is de betrouwbaarheid van elke component bepaald door de Cronbach's alpha te berekenen. Daarna is per component het gemiddelde genomen van alle items. Daardoor kon voor elke component 1 score worden opgenomen in de analyses. Boekenaanbod bestond uit maar 2 items: hiervoor is alleen een betrouwbaarheidsanalyse uitgevoerd. Ten slotte zijn two-step clusteranalyses uitgevoerd op alle componenten uit de PCA en de boekenaanbodvariabele om geletterdheidsprofielen te vormen. Met die analyses is geprobeerd om gezinnen onder te verdelen in groepen of 'clusters' die in hun geletterde gezinsklimaat erg op elkaar lijken (voor een vergelijkbare procedure, zie: Van Steensel ${ }^{9}$ en Wood $^{8}$ ).

Omdat een echte experimentele opzet (met een at random toegewezen experimentele en controlegroep en een voor- en nameting) niet mogelijk was, zijn belangrijke potentieel verstorende variabelen in kaart gebracht. Het gaat hierbij om opleiding moeder, opleiding vader, moeders moedertaal, vaders moedertaal, crèchebezoek en gezinsopvang. Bij de variabelen moedertaal van moeder en vader moet worden opgemerkt dat het (vooral) gaat om het onderscheid tussen standaard Nederlands en dialect (namelijk dat van Urk, Staphorst en Nieuwleusen). In de analyses is voor deze potentiële 'confounders' gecorrigeerd.

Voor de uiteindelijke analyses zijn gegevens van gezinnen die zijn uitgevallen 'bijgeschat' op basis van andere beschikbare gegevens. Dit gebeurde met behulp van Multivariate Imputation by Chained Equations (MICE). ${ }^{17}$

\section{Resultaten}

In tabel 1 is de verdeling weergegeven van de potentiële confounders na bijschatting, uitgesplitst voor de interventie- en controlegroep.

Aan de hand van PCA op de frequentie van geletterde activiteiten konden 4 componenten worden onderscheiden (tabel 2): kranten en tijdschriften lezen, boeken lezen, stimulerende ouder-kindactiviteiten en gebruik van elektronische media. De componenten verklaren respectievelijk $16 \%, 10 \%, 12 \%$ en $19 \%$ van de variantie in scores; de Cronbach's alpha's zijn respectievelijk o,46, 
Tabel 1. Verdeling van potentiële confounders voor de interventie- en controlegroep.

\begin{tabular}{|c|c|c|c|c|}
\hline variabelen & & $\begin{array}{l}\text { interventiegroep (\%) } \\
(n=178)\end{array}$ & $\begin{array}{l}\text { controlegroep (\%) } \\
(n=141)\end{array}$ & p-waarde \\
\hline \multirow[t]{4}{*}{ opleiding moeder } & lo & 6 & 6 & 0,88 \\
\hline & lbo, mavo & 53 & 49 & 0,49 \\
\hline & havo, vwo, mbo & 33 & 33 & 0,98 \\
\hline & hbo, wo & 7 & 12 & 0,18 \\
\hline \multirow[t]{4}{*}{ opleiding vader } & lo & 7 & 6 & 0,56 \\
\hline & Ibo, mavo & 52 & 42 & 0,06 \\
\hline & havo, vwo, mbo & 31 & 35 & 0,42 \\
\hline & hbo, wo & 9 & 18 & 0,03 \\
\hline moeders moedertaal & standaard Nederlands & 26 & 40 & 0,005 \\
\hline vaders moedertaal & standaard Nederlands & 25 & 37 & 0,02 \\
\hline \multirow[t]{4}{*}{ crèchebezoek } & 1e jaar & 12 & 48 & $<0,001$ \\
\hline & ze jaar & 5 & 24 & $<0,001$ \\
\hline & зе jaar & 16 & 30 & 0,007 \\
\hline & 4e jaar & 6 & 23 & $<0,001$ \\
\hline \multirow[t]{4}{*}{ gezinsopvang } & 1e jaar & 39 & 50 & 0,19 \\
\hline & ze jaar & 34 & 38 & 0,40 \\
\hline & зе jaar & 32 & 27 & 0,35 \\
\hline & 4e jaar & 24 & 23 & 0,98 \\
\hline
\end{tabular}

Tabel 2. Vergelijking van de scores op de 4 componenten van geletterde activiteiten, de component attitudes en het boekenaanbod in de interventie- en de controlegroep. Tevens is de score op het gezinsprofiel voor beide groepen opgenomen.

\begin{tabular}{|c|c|c|c|c|}
\hline component & score (range 1-5) & $\begin{array}{l}\text { interventiegroep } \\
(n=178)\end{array}$ & $\begin{array}{l}\text { controlegroep } \\
(n=141)\end{array}$ & adj beta \\
\hline \multirow{4}{*}{$\begin{array}{l}\text { kranten en tijd- } \\
\text { schriften lezen }\end{array}$} & gemiddelde score & $3,2(0,7)$ & $3,2(0,8)$ & 0,04 \\
\hline & kranten lezen (freq.) & $4,1(1,0)$ & $4,1(1,8)$ & 0,01 \\
\hline & tijdschrift lezen ouder (freq.) & $3,2(0,9)$ & $3,6(1,0)$ & 0,12 \\
\hline & tijdschrift lezen kind (freq.) & $2,2(1,3)$ & $2,2(1,4)$ & $-0,01$ \\
\hline \multirow[t]{3}{*}{ boeken lezen } & gemiddelde score & $3,4(0,7)$ & $3,2(0,7)$ & 0,19 \\
\hline & boeken lezen ouder (freq.) & $2,6(0,9)$ & $2,4(0,8)$ & 0,21 \\
\hline & boek lezen kind (freq.) & $4,2(0,9)$ & $4,1(1,0)$ & 0,16 \\
\hline stimulerende & gemiddelde score & $3,3(0,8)$ & $3,1(0,8)$ & 0,05 \\
\hline ouder-kind- & liedjes/rijmpjes (freq.) & $3,9(1,0)$ & $3,8(1,0)$ & 0,00 \\
\hline activiteiten & verhaaltjes (freq.) & $2,6(1,0)$ & $2,5(1,0)$ & 0,09 \\
\hline \multirow{3}{*}{$\begin{array}{l}\text { gebruik elektroni- } \\
\text { sche media }\end{array}$} & gemiddelde score & $2,2(0,9)$ & $2,4(1,0)$ & $-0,20$ \\
\hline & computeren (tijd/dag) & $2,0(0,9)$ & $2,1(1,0)$ & $-0,06$ \\
\hline & tv-kijken (tijd/dag) & $2,3(1,2)$ & $2,8(1,3)$ & $-0,34$ \\
\hline attitudes & gemiddelde score & $4,4(0,4)$ & $4,3(0,5)$ & 0,11 \\
\hline \multirow[t]{4}{*}{ boekenaanbod } & gemiddelde score & $3,9(0,8)$ & $4,0(0,7)$ & $-0,15$ \\
\hline & kinderboeken in huis & $4,5(0,7)$ & $4,6(0,7)$ & $-0,15$ \\
\hline & bibliotheekbezoek (freq.) & $3,2(1,4)$ & $3,4(1,2)$ & $-0,16$ \\
\hline & & $\begin{array}{l}\text { interventiegroep } \\
(n=178)\end{array}$ & $\begin{array}{l}\text { controlegroep } \\
(n=141)\end{array}$ & adj OR (95\%-BI) \\
\hline gezinsprofiel & totaalmaat ${ }^{a}$ & $65,5 \%$ & $50,1 \%$ & $2,0^{*}(1,1-3,7)$ \\
\hline
\end{tabular}

a: Percentage in cluster 1 = veel aandacht voor geletterdheid); adj = gecorrigeerd voor de verstorende variabelen; OR = odds ratio; $95 \%-\mathrm{BI}=95 \%$-betrouwbaarheidsinterval; ${ }^{*} p<0,05$. 
0,38, 0,46 en 0,59. De PCA van de attitude-items leverde 1 component (attitudes) op (49\% verklaarde variantie, Cronbach's alpha $=0,73$ ). Deze 5 componenten vormen samen met boekenaanbod (Cronbach's alpha $=0,24$ ) de schalen die in de effectanalyses zijn gebruikt.

In een volgende stap werden de gemiddelde scores van de interventiegroep op de 6 schalen vergeleken met die van de controlegroep, voor elk van de componenten. Na correctie voor verstorende variabelen waren er noch voor de schalen, noch voor de individuele items waaruit deze schalen bestonden significante verschillen tussen beide groepen. Dat wil zeggen dat Boekenbasgezinnen op geen van de componenten beter scoorden dan controlegezinnen. Vervolgens werden de 6 schalen ingevoerd in een clusteranalyse. Hoewel meerdere clusteroplossingen werden geprobeerd, leidde een 2-clusteroplossing tot 2 duidelijk verschillende gezinsprofielen. Het eerste cluster bestond uit gezinnen waarin relatief veel aandacht was voor zowel individuele als gezamenlijke geletterde activiteiten met het kind, waarin de attitude ten aanzien van gezamenlijke geletterde activiteiten relatief positief was, met relatief veel boekenaanbod, en met een relatief beperkte aandacht voor gebruik van elektronische media. Het tweede cluster was daarvan op alle genoemde aspecten het tegenovergestelde.

Er bleek een verschil tussen de interventie- en controlegroep wat betreft deze clusterindeling (zie onderaan in tabel 2): de Boekenbaskinderen hadden tweemaal zo veel kans om tot een gezin met het gunstige profiel te behoren als de controlekinderen. Met andere woorden, de gezinnen die aan Boekenbas hadden meegedaan, werden over het algemeen gekenmerkt door positiever(e) gedrag en attitudes ten aanzien van geletterde activiteiten dan de gezinnen die er niet aan hadden meegedaan.

\section{Discussie}

De belangrijkste bevinding in dit onderzoek is dat de Boekenbasdeelnemers tweemaal zoveel kans hadden om op te groeien in een gezin met een voor de geletterde ontwikkeling gunstiger gezinsprofiel dan de deelnemers in de controlegroep. Deze uitkomst zou een deel van de eerder beschreven positieve effecten van Boekenbas op de spraaktaalontwikkeling kunnen verklaren. Bovendien ligt deze bevinding in de lijn van de resultaten van eerder onderzoek naar de relatie tussen deelname aan family literacy programs en veranderingen in het geletterde gezinsklimaat. ${ }^{14-16}$ Opmerkelijk was dat wat betreft de schalen en items op basis waarvan de gezinsprofielen waren samengesteld, geen significante verschillen werden gevonden tussen de Boekenbasdeelnemers en de controlegezinnen. Blijkbaar zijn gezinsprofielen sensitievere effectmaten dan individuele indicatoren van het geletterde gezinsklimaat. ${ }^{9}$

Bij het onderzoek moeten enkele kanttekeningen worden geplaatst. Zo was de interventie in Staphorst vanwege de groepsbijeenkomsten iets intensiever dan in
Urk. Verder zijn de gezinnen niet at random toegewezen aan de Boekenbas- en de controlegroep. Van de groep die was gevraagd om aan Boekenbas deel te nemen, deed niet iedereen mee; degenen die aan de controlegroep waren toegewezen, deden wel allemaal mee. Mogelijk heeft dit geleid tot een selectiebias. Een vergelijking van de achtergronden van de gezinnen liet inderdaad verschillen zien tussen beide groepen: controleouders waren gemiddeld bijvoorbeeld hoger opgeleid dan Boekenbasouders, een variabele waarvan we weten dat die de leescultuur in gezinnen voorspelt. Voor deze en andere relevante kenmerken hebben we in de effectanalyses gecorrigeerd. Toch kan er nog sprake zijn van ongecontroleerde verschillen die een verstorend effect hebben op de uitkomsten, bijvoorbeeld religieuze of culturele verschillen. Als er zulke verschillen zijn, zullen die het getoonde effect van Boekenbas echter alleen maar bevestigen: gezien de samenstelling van de controlegroep in termen van opleidingsniveau zouden de ongecontroleerde verschillen in het voordeel van de controlegroep moeten zijn. Toch hebben de interventiegezinnen een positiever geletterd gezinsklimaat en dat kan, gezien de ongunstigere uitgangspositie van deze gezinnen, zeer waarschijnlijk aan Boekenbas worden toegeschreven. Ten slotte is er de mogelijkheid van informatiebias. Ouders uit de interventiegroep kunnen de vragenlijst anders hebben ingevuld dan ouders uit de controlegroep en bijvoorbeeld meer geneigd zijn geweest tot het geven van sociaalwenselijke antwoorden.

Toekomstige effectmetingen van taalstimuleringsprogramma's zouden idealiter in een gerandomiseerde studieopzet plaatsvinden. Een voormeting is gewenst en - afhankelijk van de duur van het programma - bij voorkeur ook enkele tussentijdse metingen, teneinde de relatie tussen het aanbieden van het programma en de activiteiten in het gezin beter te kunnen nagaan. Verder is het voorliggende onderzoek vooral gericht geweest op kwantitatieve aspecten van het geletterde gezinsklimaat, zoals de frequentie van bepaalde activiteiten. De kwaliteit van de ouder-kindinteractie tijdens die activiteiten is echter minstens zo belangrijk. Vervolgonderzoek zou ook daar aandacht aan moeten besteden, bijvoorbeeld door middel van observatieonderzoek. Dit geeft mogelijk inzicht in welke onderdelen van het taalstimuleringsprogramma bepalend zijn voor het effect op de geletterdheid van het gezin. Ten slotte zou, met het oog op de generaliseerbaarheid van de uitkomsten, vergelijkbaar effectonderzoek ook bij andere doelgroepen (bijvoorbeeld allochtone achterstandsgezinnen) kunnen worden uitgevoerd.

De uitkomst van dit onderzoek is goed nieuws voor voorstanders van een gezinsgerichte benadering van ontwikkelingsondersteuning van jonge kinderen. Door de introductie van de voor- en vroegschoolse educatie is de afgelopen 10 jaar veel nadruk gelegd op activiteiten in de peuterspeelzaal en de kleuterbouw van het basisonderwijs. De 
rol van het gezin bleef daarbij onderbelicht en gezinsgerichte programma's als Opstap kwamen in de verdrukking. Onze positieve bevindingen en de resultaten uit het eerdere onderzoek naar Boekenbas wijzen er echter op dat het zinvol is om in de voor- en vroegschoolse periode ook te investeren in de ondersteunende kracht van gezinnen.

\section{Literatuur}

1. Buskop-Kobussen MPHM, Nijeboer-Kuperus GJ. Stimulering van de spraaktaalontwikkeling met het programma 'Boekenbas'. Tijdschr JGZ. 2002;2:36-9.

2. Bunge-van Lent FCGM, Kleij-van Rossum A van, Bodegom S van, Rekers-Mombarg LTM, Boere-Boonekamp MM. De invloed van Boekenbas op de spraaktaalontwikkeling van kinderen van nul tot vier jaar. Eindrapport. Leiden: TNO Kwaliteit van leven; 2006.

3. Griffin EA, Morrison FJ. The unique contribution of home literacy environment to differences in early literacy skills. Early Child Dev Care. 1997;127/128:233-43.

4. Steensel R van. Voor-en vroegschoolse stimuleringsactiviteiten en ontwikkeling van geletterdheid. Amsterdam: Aksant; 2006.

5. Scarborough HS, Dobrich W. On the efficacy of reading to preschoolers. Dev Review; 1994;14:245-302.

6. Bus AG, Izendoorn MH van, Pellegrini AD. Joint book reading makes for success in learning to read. A meta-analysis on intergenerational transmission of literacy. Rev Educ Res. 1995;65:1-21.

7. Weinberger J. A longitudinal study of children's early literacy experiences at home and later literacy development at home and school. J Res Read. 1996;19:14-24.
8. Wood C. Parent-child pre-school activities can affect the development of literacy skills. J Res Read. 2002;25:241-58.

9. Steensel $R$ van. Relations between socio-cultural factors, the home literacy environment and children's literacy development in the first years of primary education. J Res Read. 2006;29:367-82

10. Burgess SR, Hecht SA, Lonigan CJ. Relations of the home literacy environment (HLE) to the development of reading-related abilities. A one-year longitudinal study. Read Res Q. 2002;37:408-26

11. Baker L, Scher D, Mackler K. Home and family influences on motivations for reading. Educ Psychol. 1997;32:69-82

12. Britto PR, Brooks-Gunn J. Beyond shared book reading. Dimensions of home literacy and low-income African American preschoolers' skills. New Dir Child Adolesc Dev. 2001;92:73-90.

13. Bunge-van Lent FCGM, Kleij van-van Rossum A, Bodegom S van, Rekers-Mombarg, LTM, Boere-Boonekamp MM. De invloed van Boekenbas op de spraaktaalontwikkeling van o- tot 4-jarigen. Tijdschr JGZ. 2007;39:52-6.

14. Morrow LM, Young J. A family literacy program connecting school and home. Effects on attitude, motivation, and literacy achievement. J Educ Psychol. 1997;89:736-42.

15. Bevans B, Furnish B, Ramsey A, Talsma S. Effective strategies for home-school partnerships in reading [ongepubliceerde masterthesis]. Chicago, IL: Saint Xavier University; 2001.

16. Needlman R, Silverstein M. Pediatric interventions to support reading aloud. How good is the evidence? J Dev Behav Pediatr. 2004; $25: 352-63$

17. Buuren S van. Multiple imputation of discrete and continuous data by fully conditional specification. Stat Methods Med Res. 2007;16:219-42.

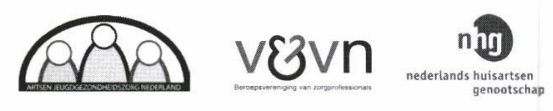

L. de Vries, M.M. Boere-Boonekamp, A.J. Klein Ikkink, L.J. Boomsma, J. Heetman-Cleton, M. Kamphuis, C.M. Lobo, P. Mentink, I. Middeldorp, L.F. van Raalte en B.E. van Sleuwen

\section{Landelijke Eerstelijns Samenwerkings Afspraak Enuresis nocturna}

Dit artikel is tevens gepubliceerd in Huisarts en Wetenschap 2011;(54)4:\$5-9.

Inbreng van het kind en zijn ouders

Een LESA geeft aanbevelingen voor samenwerking en werkafspraken tussen huisartsen en andere eerstelijnshulpverleners. Doel is dat het kind en zijn ouders in de eerste lijn op het juiste moment de juiste hulp krijgen met behoud van de continuïteit in de zorg.
Hulpverleners in de eerste lijn stellen altijd in samenspraak met het kind en/of zijn ouders het beleid vast en stemmen hun behandeling af op de hulpvraag van het kind. Zij houden daarbij rekening met zijn specifieke omstandigheden. Om praktische redenen staat dit niet overal expliciet in de LESA vermeld. Hulpverleners

Namens het Nederlands Huisartsen Genootschap (NHG): L.J. Boomsma, A.J. Klein Ikkink, C.M. Lobo, L.F. van Raalte, L. de Vries, allen huisarts. Namens de artsen Jeugdgezondheidszorg Nederland (AIN): M.M. Boere-Boonekamp en J. Heetman-Cleton, beiden arts maatschappij en gezondheid profiel JGZ; M. Kamphuis, jeugdarts KNMG en B.E. van Sleuwen, biologe. Namens de Verpleegkundigen \& Verzorgenden Nederland (VV\&VN): P. Mentink, verpleegkundig specialist preventie en I. Middeldorp, jeugdverpleegkundige. 